\title{
SINTESIS DAN KARAKTERISASI BORON KARBIDA DARI ASAM BORAT, ASAM SITRAT DAN KARBON AKTIF
}

\author{
Dini Harsanti, S.Si, M.Si ${ }^{1}$
}

\begin{abstract}
Boron carbide is highly refractory material that is of great interest for both it's structural and electronic properties. Of particular importance are it's high-temperature stability, high hardness, high cross-section for neutron capture, and excellent high-temperature thermoelectric properties. This combination of properties gives rise to numerous applications, including uses as an abrasive wear-resistant material, ceramic armor, a neutron moderator in nuclear reactors, and potentially, for power generating deep space flight applications. This experimental succesfull to synthesis $B_{4} C$ boron carbide that has rhombohedral crystal system, space grup $m 3 R$, and lattice constant $a=b=5,600, c=12,08, \alpha=\beta=\gamma=90^{\circ}$ by using raw materials i.e. boric acid $\left(\mathrm{H}_{3} \mathrm{BO}_{3}\right)$, activated carbon, and citric acid $\left(\mathrm{C}_{6} \mathrm{H}_{8} \mathrm{O}_{7}\right)$ and magnesium as co-reductant.
\end{abstract}

\section{Intisari}

Boron karbida merupakan material yang sulit terbentuk yang memiliki struktur dan aplikasi elektronik yang menarik. Beberapa kelebihan yang dimiliki oleh boron karbida antara lain stabil pada temperatur tinggi, memiliki tingkat kekerasan yang tinggi, berkemampuan tinggi dalam menyerap neutron pada pusat reaktor nuklir, dan memiliki sifat-sifat termoelektrik yang sangat baik. Kombinasi dari sifat-sifat tersebut memungkinkan boron karbida digunakan dalam berbagai aplikasi, termasuk material yang tahan abrasi, persenjataan militer, moderator neutron pada reaktornuklir, dan berpotensial diaplikasikan pada pembangkit daya penerbangan angkasa luar. Penelitian ini berhasil mensintesis boron karbida dengan fasa $B_{4} C$ yang memiliki sistem Kristal rhombohedral, space grup $m 3 R$, dan parameter kisi $a=b=5,600, c=12,08$, $\alpha=\beta=\gamma=90^{\circ}$ dengan menggunakan bahan-bahan awal berupa asam borat $\left(\mathrm{H}_{3} \mathrm{BO}_{3}\right)$, karbon aktif, dan asam sitrat $\left(\mathrm{C}_{6} \mathrm{H}_{8} \mathrm{O}_{7}\right)$ yang ditambahkan dengan magnesium sebagai koreduktor.

\section{Kata kunci: Boron Karbida, Asam Borat,Karbon Aktif, Asam Sitrat, mechanical milling, dan} ball mil

\section{PENDAHULUAN}

Boron karbida merupakan material yang sulit terbentuk yang memiliki struktur dan aplikasi elektronik yang menarik. Boron karbida merupakan salah satu material terkeras yang diproduksi secara besar-besaran. Pertama kali ditemukan pada pertengahan abad ke-19 sebagai produk sampingan dalam produksi metal borida. Boron karbida mulai dipelajari secara detail sejak tahun 1930. Dengan tingkat kekerasan 9,3 skala mohs, boron karbida menduduki peringkat kelima dari material terkeras yang pernah diketahui setelah boron nitrida, intan, ultrahard fullerite, dan aggregated diamond nanorods. Beberapa kelebihan yang dimiliki oleh boron karbida antara

\footnotetext{
Perekayasa UPT Hujan Buatan BPP Teknologi,

E-mail:dini_harsa@yahoo.com
}

lain stabil pada temperatur tinggi, memiliki tingkat kekerasan yang tinggi, berkemampuan tinggi dalam menyerap neutron pada pusat reaktor nuklir, dan memiliki sifat-sifat termoelektrik yang sangat baik. Kombinasi dari sifat-sifat tersebut memungkinkan boron karbida digunakan dalam berbagai aplikasi, termasuk material yang tahan abrasi, persenjataan militer, moderator neutron pada reaktor nuklir, dan berpotensial diaplikasikan pada pembangkit daya penerbangan angkasa luar

Produksi boron karbida pada skala industri diperoleh dengan cara klasik, yaitu reduksi karbotermal darioksida borat $\mathrm{B}_{2} \mathrm{O}_{3}$ pada temperature tinggi. Sebagai alternatif lain, $\mathrm{B}_{4} \mathrm{C}$ dapat dibuat dengan cara coating (pelapisan) pada substrat yang sesuai dengan teknik reaksi fasa uap (vapour phase reaction) misalnya menggunakan boron halida atau diboran dengan metana atau sumber 
karbon kimia lainnya. Dalam banyak penelitian sebelumnya, digunakan temperatur yang sangat tinggi ketika pirolisis. Dengan demikian, usaha untuk mensintesis boron karbida pada temperatur rendah merupakan suatu keuntungan secara ekonomi. Pada penelitian ini, prekursor yang mengandung boron disintesis dengan mereaksikan asam borat, karbon dan asam sitrat.

\subsection{Tujuan Penelitian}

Tujuan dari penelitian ini adalah mengembangkan proses manufaktur yang murah dan menggunakan temperatur rendah untuk mensintesis boron karbida dari raw material/bahan baku yang murah dan mudah diperoleh. Secara terperinci tujuan dari penelitian ini adalah

1. Mempelajari pembentukan boron karbida dengan bahan dasar asam borat, karbon, dan asam sitrat.

2. Mengetahui komposisi bahan awal yang optimal untuk pembentukan boron karbida dari reaksi asam borat-karbon dan asam borat-karbonasam sitrat.

3. Mengetahui struktur kristal boron karbida yang terbentuk dari hasil reaksi bahan-bahan awal melalui XRD dengan bantuan software GSAS dan pembentukan ikatan boron-karbon dengan FTIR.

\subsection{Ruang Lingkup Penelitian}

Penelitian yang dilakukan hanya dibatasi pada masalah bagaimana proses sintesis boron karbida dari bahan asam borat, karbon, dan asam sitrat dengan memvariasikan komposisi bahanbahan, memvariasikan jenis karbon dan pengaruh penggunaan katalis terhadap pembentukan boron karbida dan struktur kristal yang dihasilkan.

\subsection{Manfaat Penelitian}

Dari hasil penelitian ini, diharapkan mampu memproduksi boron karbida dengan menggunakan bahan-bahan yang banyak tersedia dan harganya murah. Boron karbida yang dihasilkan dari penelitian ini bisa dimanfaatkan untuk berbagai keperluan, seperti pelapisan, sebagai campuran pelat komposit, dan lain sebagainya.

\subsection{Hipotesis}

1. Diharapkan pada temperatur rendah $850^{\circ} \mathrm{C}$ sudah terjadi pembentukan boron karbida $\mathrm{B}_{4} \mathrm{C}$.
2. Jenis sumber karbon yang digunakan ikut mempengaruhi reaksi pembentukan boron karbida $\mathrm{B}_{4} \mathrm{C}$.

3. Penambahan asam sitrat dapat memperbesar peluang terbentuknya boron karbida $\mathrm{B}_{4} \mathrm{C}$.

4. Penggunaan koreduktor magnesium dapat menurunkan temperature reaksi pembentukan boron karbida $\mathrm{B}_{4} \mathrm{C}$.

\section{Tinjauan Pustaka}

\subsection{Boron Karbida}

Boron karbida mempunyai rumus kimia $\mathrm{B}_{4} \mathrm{C}$. Pada awalnya boron karbida ditemukan pada pertengahan abad ke-19 sebagai produk sampingan dari produksi logam borit. Boron karbida dipelajari secara teliti sejak tahun 1930. Boron karbida merupakan material yang sulit terbentuk yang memiliki struktur dan aplikasi elektronik yang menarik [7]. Beberapa kelebihan yang dimiliki oleh boron karbida antara lain stabil pada temperatur tinggi, memiliki tingkat kekerasan yang tinggi, berkemampuan tinggi dalam menyerap neutron pada pusat reaktor nuklir, dan memiliki sifat-sifat termoelektrik yang sangat baik. Kombinasi dari sifat-sifat tersebut memungkinkan boron karbida digunakan dalam berbagai aplikasi, termasuk material yang tahan abrasi, persenjataan militer, moderator neutron pada reaktor nuklir, dan berpotensial diaplikasikan pada pembangkit daya penerbangan angkasa luar [10]. Boron karbida memiliki struktur kristal rhombohedral dengan 12 atom icosahedra yang terikat dengan ikatanikatan kovalen dan rantairantai yang terdiri dari tiga atom intericosahedral di sepanjang diagonal utama rhombohedron. Kristal boron karbida memiliki rentang homogenitas yang lebar mulai dari $\mathrm{B}_{10 \cdot 4} \mathrm{C}$ hingga $\mathrm{B}_{4^{*} 3} \mathrm{C}$. Rentang yang lebar dari rasio $B / C$ pada boron karbida ini disebabkan oleh replacement atom-atom boron dengan atom-atom karbon di sepanjang rantai-rantai intericosahedral dan icosahedra [3].

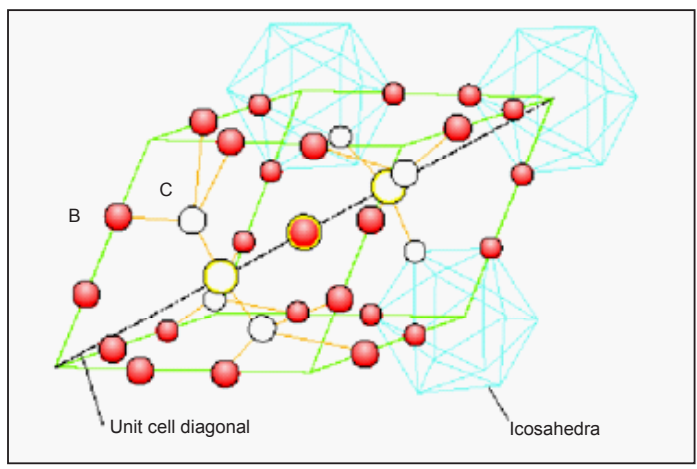

Gambar 2.1 Struktur unit $\mathrm{B}_{4} \mathrm{C}$ rhombohedral 
Pemanfaatan boron karbida antara lain: sebagai bahan abrasive dalam pemolesan dan pelapisan, sebagai nozzel untuk slurry pumping, sebagai penyerap untuk radiasi neutron yang muncul pada pusat pembangkit listrik tenaga nuklir, sebagai rudal balistik, dan sebagai perisai untuk menahan peluru-peluru yang berkecepatan tinggi [11].

\subsection{Asam Borat}

Asam borat memiliki massa molar 61,832 $\mathrm{gram} / \mathrm{mol}$ dan densitas sebesar $1,435 \mathrm{~g} / \mathrm{cm}^{3}$. Asam borat larut dalam air dengan kelarutan 5,7 gram tiap $100 \mathrm{ml}$ air pada temperatur $25^{\circ} \mathrm{C}$. Fasa kristalin asam borat terdiri dari layer-layer molekul $\mathrm{B}(\mathrm{OH})_{3}$ yang diikat bersama oleh ikatan hydrogen (Gambar 2.2a dan 2.2b). Jarak antara dua layer yang berdekatan adalah $318 \mathrm{pm}$. Pada saat dipanaskan di atas suhu $170^{\circ} \mathrm{C}$ asam borat akan kehilangan air dan membentuk asam metaborat atau $\mathrm{HBO}_{2}$. Asam metaborat adalah suatu bentuk padatan berwarna putih dengan sistim kristal kubik dan sedikit larut dalam air. Titik leburnya sekitar $236^{\circ} \mathrm{C}$, ketika dipanaskan di atas suhu $300 \mathrm{oC}$ akan mengalami kehilangan air dan membentuk Asam Tetraborat atau Asam Pyroborat $\left(\mathrm{H}_{2} \mathrm{~B}_{4} \mathrm{O}_{7}\right)$. Asam borat terdapat dalam bentuk tiga fasa ini. Pemanasan lebih lanjut akan membentuk boron trioksida [11]. Asam Borat tidak terdisosiasi dalam larutan (air), tetapi asamnya yang akan berinteraksi dengan molekul air dengan melalui suatu reaksi kimia

$$
\mathrm{B}(\mathrm{OH})_{3}+\mathrm{H}_{2} \mathrm{O} \quad \mathrm{B}(\mathrm{OH})^{4-}+\mathrm{H}^{+}
$$

Anion poliborat terbentuk pada $\mathrm{pH} 7-10$ jika konsentrasi boron lebih dari $0,025 \mathrm{~mol} / \mathrm{L}$, ini disebut tetraborat ion yang terdapat dalam mineral boraks dengan persamaan reaksi

$4 \mathrm{~B}(\mathrm{OH})^{4-}+2 \mathrm{H}^{+} \quad \mathrm{B}_{4} \mathrm{O}_{7}^{2-}+9 \mathrm{H}_{2} \mathrm{O}$

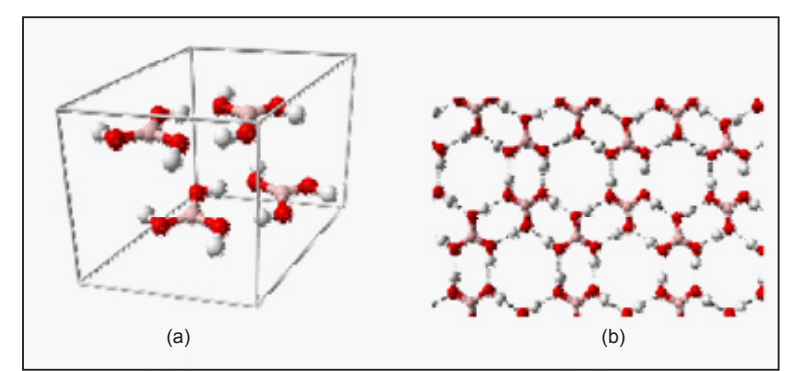

Gambar 2.2 (a) Unit sel asam borat, (b) Ikatan hidrogen

\subsection{Karbon Aktif}

Karbon aktif pertama kali menjadi menonjol karena penggunaannya sebagai absorben dalam topeng gas pada Perang Dunia I. Karbon aktif dapat dibagi atas dua golongan utama; yang digunakan dalam adsorpsi gas dan uap, biasanya berbentuk butiran, dan yang digunakan untuk memurnikan zat cair, biasanya berbentuk serbuk. Karbon aktif banyak digunakan pada berbagai proses industri. Sebagai penghilang warna, karbon aktif yang mempunyai luas permukaan yang sangat besar, demikian juga volume porinya, jauh lebih efisien daripada arang kayu. Luas permukaan spesifiknya berkisar antara 300 sampai $2500 \mathrm{~m}^{2} / \mathrm{g}$. Kuantitas bahan yang diserap oleh karbon aktif sangat besar, dan uap seperti uap bensin, benzena, dan karbon tetraklorida yang diserapnya kadang-kadang mencapai seperempat berat bahkan sama dengan berat adsorbennya. Bahan-bahan yang diserap sangat bergantung pada luas permukaan dan volume pori. Struktur pori menyebabkan ukuran molekul yang dapat diserap menjadi terbatas, sedangkan jika ukuran partikelnya tidak menjadi masalah, kuantitas bahan yang diserap dibatasi oleh luas permukaan adsorben. Penggunaan karbon aktif terutama adalah untuk pemurnian larutan, misalnya pembersihan larutan gula tebu, gila bit, dan gula jagung, dan untuk menghilangkan rasa dan bau air minuman, minyak nabati dan gemuk hewani, minuman alkohol, bahan kimia, dan bahan obat-obatan. Karbon aktif jenis adsorben uap pertama kali digunakan dalam topeng pelindung gas karena bahan ini mampu menyerap gas-gas beracun, dan sekarang banyak dipakai dalam topeng gas untuk penggunaan militer maupun industri.

Karbon aktif digunakan dalam sistem penyaman hawa untuk mengendalikan bau di dalam restoran-restoran besar, auditorium, dan ruang-ruang bandara udara. Salah satu bidang penerapannya yang penting adalah pemulihan dan pengendalian uap di industri. Karbon aktif dapat digunakan untuk menyerap hampir semua jenis pelarut organic pada suhu sekitar $35^{\circ} \mathrm{C}$. Bila hendak memulihkannya kembali, pelarut dilepaskan dari adsorben dengan memanaskannya pada suhu $120^{\circ} \mathrm{C}$ atau lebih. Berbagai bahan berkarbon, seperti kokas migas, serbuk gergaji, lignit batu bara, gambut, kayu, arang batok, dan biji buah-buahan dapat digunakan untuk membuat karbon aktif. Sifatsifat bahan jadinya tidak hanya bergantung pada bahan baku yang digunakan, tetapi juga pada cara aktivasi. Karbon aktif untuk penghilangan warna biasa digunakan dalam bentuk serbuk. Jadi, bahan baku untuk jenis ini haruslah tanpa struktur atau mempunyai struktur lemah. Untuk menghasilkan jenis ini, dapat digunakan serbuk gergaji atau lignit. Karbon adsorben uap digunakan dalam bentuk granula keras dan biasanya dibuat dari batok kelapa, biji buah, atau batu bara dan arang kayu yang dibuat brikat (bata). Sifat fisikanya yang paling penting adalah luas permukaan. Aktivasi adalah perubahan fisika di mana permukaan karbon itu 
menjadi jauh lebih banyak karena hidrokarbonnya disingkirkan. Ada beberapa metode yang dapat digunakan dalam melakukan aktivasi. Cara yang paling umum digunakan adalah perlakuan bahan berkarbon dengan gas pengoksidasi seperti udara, uap atau karbon dioksidasi, dan karbonisasi bahan baku dengan bahan kimia seperti seng klorida atau asam fosfat. Hampir seluruh karbon aktif yang dibuat di AS dibuat dengan metode aktivasi uap pemanas. Metode aktivasi kimia masih banyak digunakan di Eropa dan negara-negara lain.

\subsection{Asam Sitrat}

Asam sitrat merupakan asam organik lemah yang ditemukan pada daun dan buah tumbuhan genus sitrus (jeruk-jerukan). Senyawa ini merupakan bahan pengawet yang baik dan alami, selain digunakan sebagai penambah rasa asam pada makanan dan minuman ringan. Dalam biokimia, asam sitrat dikenal sebagai senyawa antara dalam siklus asam sitrat, yang penting dalam metabolisme makhluk hidup. Asam sitrat dapat juga digunakan sebagai zat pembersih yang ramah lingkungan dan sebagai antioksidan. Asam sitrat terdapat pada berbagai jenis buah dan sayuran, namun ditemukan pada konsentrasi yang tinggi, yang dapat mencapai $8 \%$ bobot kering pada jeruk, lemon, dan limau. Asam sitrat mempunyai rumus kimia $\mathrm{C}_{6} \mathrm{H}_{8} \mathrm{O}_{7}$. Nama IUPAC-nya adalah 2-hidroksi1,2,3-propana tri karboksilat. Keasaman asam sitrat didapatkan dari tiga gugus karboksil $\mathrm{COOH}$ yang melepas proton dalam larutan. Jika hal ini terjadi, ion yang dihasilkan adalah ion sitrat. Sitrat sangat baik digunakan dalam larutan penyangga (buffer) untuk mengendalikan $\mathrm{pH}$ larutan. Ion sitrat dapat bereaksi dengan banyak ion logam dengan pengkelatan, sehingga digunakan sebagai pengawet dan penghilang kesadahan air. Pada temperatur kamar, asam sitrat berbentuk serbuk Kristal berwarna putih. Serbuk kristal ini dapat berupa bentuk anhydrous (bebas air) atau bentuk monohidrat yang mengandung satu molekul air untuk setiap molekul asam sitrat. Secara kimia, asam sitrat bersifat seperti asam karboksilat lainnya, jika dipanaskan di atas temperatur $175^{\circ} \mathrm{C}$ asam sitrat terurai dengan melepaskan karbon dioksida dan air.

\subsection{Magnesium}

Magnesium adalah suatu logam yang sangat ringan, berwarna putih perak dan sangat banyak digunakan dalam industri. Magnesium adalah logam kedelapan terbanyak di dunia. Bahan bakunya tersebar di seluruh dunia, terlebihlebih karena air laut merupakan sumber senyawa magnesium yang paling praktis dan paling utama.
Sumber yang utama adalah dolomite $\left(\mathrm{CaCO}_{3}\right.$. $\left.\mathrm{MgCO}_{3}\right)$, magnesit $\left(\mathrm{MgCO}_{3}\right)$ dan karnalit $\left(\mathrm{MgCl}_{2}\right.$. $\left.\mathrm{KCl} .6 \mathrm{H}_{2} \mathrm{O}\right) .1 \mathrm{~km}^{3}$ air laut mengandung $1,3 \times 106$ ton magnesium. Dengan demikian tidak akan ada kekurangan bahan baku yang ekonomis untuk pembuatan logam magnesium dan garamgaramnya. Pemakaian magnesium, logam teringan di dunia, yang terbesar adalah untuk membuat paduan dengan aluminium untuk digunakan dalam berbagai penerapan, seperti pesawat antariksa dan bagian-bagian kendaraan bermotor. Penggunaan lainnya adalah sebagai zat pereaksi Grignard, piroteknik, dan bahan peledak, anode korban untuk pencegahan korosi, rumahan ringan untuk peralatan tenaga dan kendaraan bermotor, dan sebagai bahan pereduksi dalam pembuatan titanium, zirkonium, uranium, dan berilium. Cara yang paling murah untuk membuat magnesium adalah dengan proses elektrolisis. Pada masa Perang Dunia II, magnesium dibuat juga dengan dua buah proses lain, yaitu proses silikotermik atau proses ferosilikon dan proses reduksi karbon.

\subsection{Proses Sintesis Boron Karbida}

Bubuk boron karbida terutama dibuat dengan cara mereaksikan karbon dengan $\mathrm{B}_{2} \mathrm{O}_{3}$ dalam sebuah furnace listrik, melalui reduksi karbotermal atau melalui reaksi-reaksi fasa gas. Untuk penggunaan secara komersial, bubuk $\mathrm{B}_{4} \mathrm{C}$ biasanya dihaluskan dan dimurnikan untuk menghilangkan logam-logam pengotor. Sebagai alternatif lain, $\mathrm{B}_{4} \mathrm{C}$ dapat dibuat dengan cara pelapisan (coating) pada substrat yang sesuai dengan teknik reaksi fasa uap (vapour phase reaction) misalnya menggunakan boron halida atau diboran dengan metana atau sumber karbon kimia lainnya. Zhang et al. mendiskusikan manfaat material boron karbida skala nano dan mendemonstrasikan penggunaan plasma-enhanced chemical vapor deposition untuk membuat kawat berukuran nano dari boron karbida. Han et al. melaporkan pembentukan kristalin nanorod boron karbida dan boron-doped nanotubes sebagai hasil reaksi dari uap boron oksida dengan karbon nanotubes. Pender et al. melaporkan metode yang langsung dan sederhana untuk pembentukan serat nano monodispersed boron karbida berdasarkan pada penggunaan teknik porous alumina templating dalam kombinasi dengan prekursor single-source molecular baru. Mirabelli et al. melaporkan teknik baru yang selektif untuk boron karbida dan boron nitrit berdasarkan penggunaan sistem polimer baru, poly[2-(vinyl) pentaborane] dan poly[B-vinylborazine], sebagai prekursor. Reaksi 2- $\left(\mathrm{H}_{2} \mathrm{C}=\mathrm{CH}\right) \mathrm{B}_{5} \mathrm{H}_{8}$ dapat berlangsung pada panas polimerisasi menjadi vinylpentaborane oligomer dan spesies ini dapat dikonversi menjadi boron karbida murni $\left(\mathrm{B}_{4} \mathrm{C}\right)$ pada 
temperatur sedang. Isao et al. melaporkan bahwa asam borat dan 2-hidroksibenzil alkohol (HBA) digunakan sebagai sumber $\mathrm{B}$ dan $\mathrm{C}$ dari $\mathrm{B}_{4} \mathrm{C}$. $\mathrm{H}_{3} \mathrm{BO}_{3}$ dan HBA dalam larutan DMF menghasilkan hibrida phenolic resin- $\mathrm{B}_{2} \mathrm{O}_{3}$. Pemberian panas pada bubuk hibrida ini pada temperatur $1500^{\circ} \mathrm{C}$ dalam gas argon selama 4 jam menghasilkan pembentukan bubuk $B_{4} C$. Boron karbida juga dapat dihasilkan dari proses karbotermal dengan menggunakan asam borat dan asam sitrat sebagai bahan baku. Larutan asam borat dalam asam sitrat membentuk jeli yang stabil pada $\mathrm{pH}$ tertentu. Dengan melakukan pirolisis pada kondisi vakum menghasilkan bubuk prekursor yang terdiri dari boron oksida dan karbon. Prekursor ini dipanaskan pada kondisi vakum mulai dari $500 \mathrm{C} / \mathrm{jam}$ hingga $1450^{\circ} \mathrm{C}$ dan produk yang didapat diperiksa dengan XRD, analisis kimia, dan SEM. Pola XRD menunjukkan bahwa produk terdiri dari $\mathrm{B}_{4} \mathrm{C}$ dan karbon. Metode alternatif lain dalam mensintesis boron karbida adalah dengan reduksi magnesiotermis dari boron oksida dan karbon melalui reaksi kimia berikut

$$
2 \mathrm{~B}_{2} \mathrm{O}_{3}(\mathrm{l})+6 \mathrm{Mg}(\mathrm{s})+\mathrm{C}(\mathrm{s}) \rightarrow \mathrm{B}_{4} \mathrm{C}(\mathrm{s})+6 \mathrm{MgO}(\mathrm{s}) \text {. }
$$

Reaksi ini berlangsung secara eksotermis dan dilakukan dalam furnace dengan menggunakan tube karbon dan dialiri gas hidrogen. Produk ini kemudian dipurifikasi melalui pemanasan dalam vakum pada temperature $1800^{\circ} \mathrm{C}$. MgO bertindak sebagai inhibitor penumbuh partikel, dan bubuk boron karbida yang sangat halus dengan ukuran $0,1-1,5 \mu \mathrm{m}$ dapat diperoleh dengan reaksi ini. $\mathrm{MgO}$ dan $\mathrm{Mg}$ yang tidak habis bereaksi dihilangkan dengan pencucian asam $\left(\mathrm{H}_{2} \mathrm{SO}_{4}\right)$. Penelitian tentang pembuatan boron karbida pada temperature rendah sudah dipublikasikan oleh beberapa peneliti. Mondal, et al. 26,4 g (0,6 mol) polivinil alkohol (PVA) dilarutkan dengan $500 \mathrm{ml}$ air dalam gelas beaker dan dipanaskan. 12,366 gram $(0,2$ mol) asam borat $\mathrm{B}(\mathrm{OH})_{3}$ dilarutkan dengan $250 \mathrm{ml}$ air dalam gelas beaker dan dipanaskan. Kemudian larutan asam borat ditambahkan ke dalam larutan PVA sambil terus diaduk secara konstan dengan menggunakan batang kaca. Kemudian diperoleh material yang lunak seperti permen karet dan berwarna putih. Material ini dikeringkan dalam oven bersuhu sekitar $100^{\circ} \mathrm{C}$. Material yang telah kering kemudian diubah menjadi bubuk. Reaksi yang mungkin antara asam borat dan polivinil alcohol adalah sebagai berikut Bubuk prekursor ini kemudian diletakkan dalam wadah porselin dan dipanaskan dalam furnace. Pemanasan dilakukan secara bertahap dengan laju pemanasan $120^{\circ} \mathrm{C}$ per jam hingga temperatur yang diinginkan tercapai. Pirolisis dari campuran prekursor ini dalam udara selama 3 jam menghasilkan boron karbida pada temperatur $400^{\circ} \mathrm{C}$ dan $800^{\circ} \mathrm{C}$. Shi et al. berhasil mensintesis powder $\mathrm{B}_{4} \mathrm{C}$ yang sangat halus pada temperatur $450^{\circ} \mathrm{C}$ dengan menggunakan $\mathrm{BBr}_{3}$ dan $\mathrm{CCl}_{4}$ sebagai reaktan dan logam $\mathrm{Na}$ sebagai koreduktan. Reaksi kimia yang berlangsung adalah sebagai berikut

$\mathrm{CCl}_{4}+4 \mathrm{BBr}_{3}+16 \mathrm{Na} \mathrm{B}{ }_{4} \mathrm{C}+4 \mathrm{NaCl}+12 \mathrm{NaBr}$.

Eksperimen dilakukan di dalam dry glove box dengan mengalirkan gas argon. 8 gram logam $\mathrm{Na}$ (berlebih), 5,5 $\mathrm{ml} \mathrm{BBr}_{3}$ dan 1,4 $\mathrm{ml} \mathrm{CCl}_{4}$ diletakkan dalam tabung besi dan ditutup dalam sebuah autoclave berkapasitas $50 \mathrm{ml}$. Autoclave kemudian dioperasikan pada suhu $450^{\circ} \mathrm{C}$ selama 8 jam, dan kemudian didinginkan ke temperatur ruangan. Produk hasil reaksi kemudian dicuci berturut-turut dengan etanol murni, larutan asam hidroklorit dan air suling, untuk menghilangkan $\mathrm{NaCl}$ dan impuritas lainnya. Setelah itu dikeringkan dalam vakum pada temperatur $60^{\circ} \mathrm{C}$ selama 6 jam sehingga diperoleh bubuk berwarna abu-abu.

\section{METODE PENELITIAN DAN PROSEDUR EKSPERIMEN}

Sesuai dengan tujuan penelitian seperti yang telah disebutkan pada Bab 1 dan kerangka konsep pada Bab 2, maka untuk mendapatkan material dengan struktur boron karbida $\left(\mathrm{B}_{4} \mathrm{C}\right)$ dilakukan penelitian pembuatan material dengan metode pencampuran reaktan dan powder metalurgi yang merupakan metode yang banyak digunakan oleh sebagian besar literatur. Percobaan dilanjutkan dengan pemeriksaan menggunakan hamburan sinar x (XRD), FTIR, dan DTA. Skematik percobaan tertera pada Gambar 3.1, skematik langkah-langkah pencucian bahan awal dengan larutan $\mathrm{HCl}$ tertera pada Gambar 3.2, dan skematik variasi komposisi sampel dalam percobaan tertera pada Gambar 3.3.

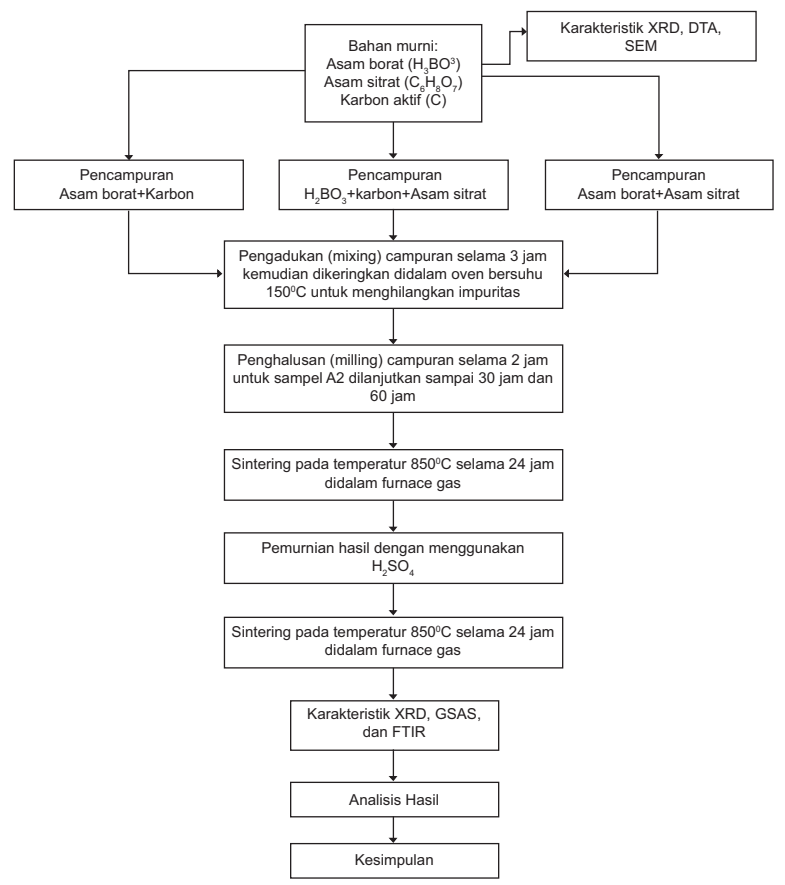

Gambar 3.1 Skema sintesis material $\mathrm{B}_{4} \mathrm{C}$ 


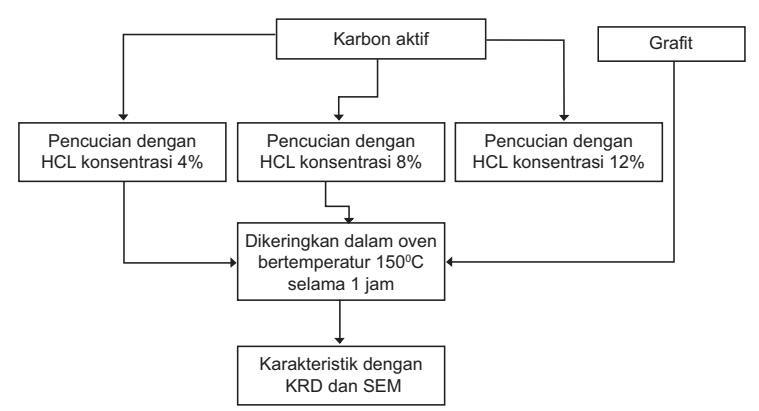

Gambar 3.2 Skema pencucian karbon dengan $\mathrm{HCL}$

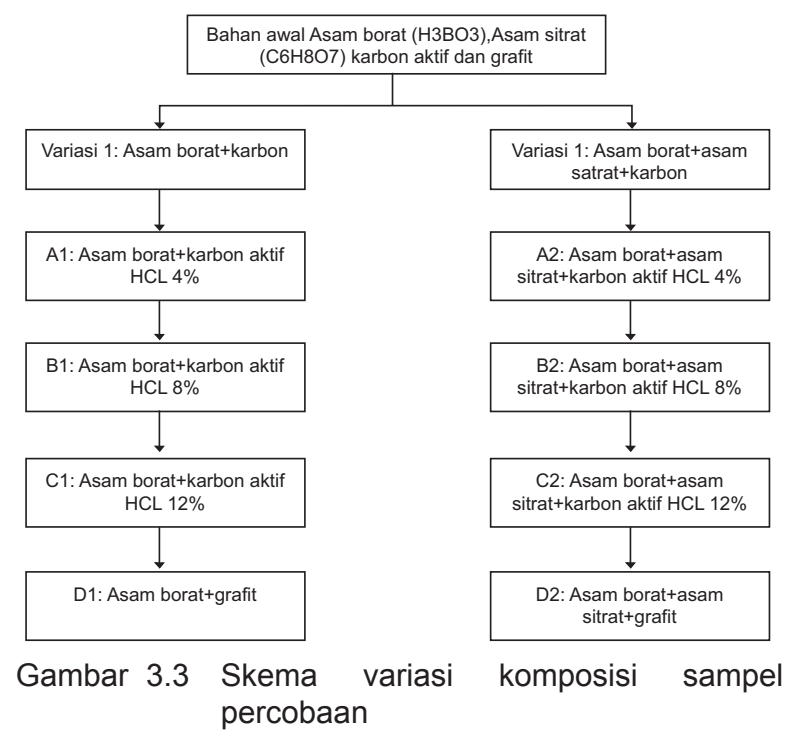

\subsection{Pembuatan Material Boron Karbida}

Proses preparasi sampel terdiri dari proses penimbangan, pencampuran (mixing) dan penghalusan (milling). Proses penimbangan dilakukan dengan menggunakan neraca analitis tipe Bosch Sae 200. Proses pencampuran dilakukan di atas kompor listrik sambil diaduk konstan hingga semua bahan tercampur secara merata. Preparasi sampel tahap awal ini menggunakan variasi komposisi yaitu:

1. Asam borat + karbon dengan perbandingan mol $4: 7$

2. Asam borat + karbon + asam sitrat dengan perbandingan mol $4: 6: 1$

3. Asam borat + asam sitrat dengan perbandingan mol $4: 7$

Untuk mengetahui berat masing-masing sampel maka mol dikonversi ke dalam massa (gram). Cara melakukan konversi dari mol ke gram masing-masing sampel ditentukan berat molekulnya (BM) terlebih dahulu

- $\mathrm{BM} \mathrm{H}_{3} \mathrm{BO}_{3}=62 \mathrm{gram} / \mathrm{mol}$

- BM karbon aktif = $12 \mathrm{gram} / \mathrm{mol}$

- $\mathrm{BM} \mathrm{C}_{6} \mathrm{H}_{8} \mathrm{O}_{7} \mathrm{H}_{2} \mathrm{O}=210 \mathrm{gram} / \mathrm{mol}$

Penentuan komposisi sampel berdasarkan reaksi berikut :

$$
4 \mathrm{H}_{3} \mathrm{BO}_{3}+7 \mathrm{C} \quad \mathrm{B}_{4} \mathrm{C}+6 \mathrm{CO}+6 \mathrm{H}_{2} \mathrm{O}
$$

Perhitungan massa untuk masing-masing reaktan adalah sebagai berikut.

$4 \mathrm{~mol} \mathrm{H}_{3} \mathrm{BO}_{3}=4 \times \mathrm{BM} \mathrm{H}_{3} \mathrm{BO}_{3}=4 \times 62$ gram $=248$ gram. Untuk 0,4 mol $\mathrm{H}_{3} \mathrm{BO}_{3}=24,8$ gram. $7 \mathrm{~mol} \mathrm{C}$ $=7 \times \mathrm{BM} \mathrm{C}=7 \times 12$ gram $=84$ gram. Untuk 0,7 mol $\mathrm{C}=8,4$ gram. Asam sitrat $(\mathrm{C} 6 \mathrm{H} 8 \mathrm{O} 7)$ dilihat dari produk $\mathrm{CO}$ adalah $6 \mathrm{CO}$. Mol asam sitrat = $\mathrm{BM} \mathrm{C}_{6} \mathrm{H}_{8} \mathrm{O}_{7} / 6=210 / 6=35$ gram. Untuk 0,1 mol $\mathrm{C}_{6} \mathrm{H}_{8} \mathrm{O}_{7}=3,5 \mathrm{gram}$. Dengan demikian reaktan yang direaksikan masing-masing adalah :

\begin{tabular}{|c|c|c|c|}
\hline No. & $\begin{array}{c}\text { Asam borat } \\
\text { (gram) }\end{array}$ & $\begin{array}{c}\text { Karbon } \\
\text { (gram) }\end{array}$ & $\begin{array}{c}\text { Asam sitrat } \\
\text { (gram) }\end{array}$ \\
\hline 1. & 24,8 & 6,4 & 0 \\
\hline 2. & 24,8 & 7,2 & $3,5(1 \mathrm{x})$ \\
\hline 3. & 24,8 & 0 & $24,5(1 \mathrm{x})$ \\
\hline
\end{tabular}

Komposisi ini kemudian divariasikan lagi dengan memodifikasi sumber karbon (C), yaitu dengan menggunakan karbon aktif komersial dan grafit. Uraian modifikasi sumber karbon adalah sebagai berikut.

1. Karbon akftif komersial yang telah dimodifikasi dengan mencucinya terlebih dahulu menggunakan asam klorida ( $\mathrm{HCl})$ masing-masing dengan konsentrasi $\mathrm{HCl} 4 \%$, 8\%, dan 12\%.

2. Grafit dengan kemurnian $99 \%$

Preparasi dilanjutkan dengan mencampur masing-masing komposisi sampel ke dalam gelas ukur yang berisi $100 \mathrm{ml}$ air murni (akuades) untuk melarutkan reaktan. Pencampuran ini dilakukan di atas kompor listrik bersuhu $150^{\circ} \mathrm{C}$ selama 1 jam hingga semua bahan tercampur rata. Sampel kemudian dipanaskan dalam oven listrik bertemperatur $150^{\circ} \mathrm{C}$ selama 1 jam dengan tujuan untuk menghilangkan air dan zat impuritas lainnya. Dari variasi komposisi ini didapatkan sepuluh (10) sampel yang diberi label A1, A2, B1, B2, C1, C2, D1, dan D2. Setelah sampel-sampel dikeringkan dalam oven, dilakukan penghalusan ukuran butir (milling) selama 2 jam sehingga diperoleh sampelsampel yang berbentuk bubuk. Untuk sampel A2 dilanjutkan dengan memvariasikan waktu milling selama 30 jam dan 60 jam. Penghalusan sampel ini menggunakan metode ballmill dengan menggunakan mesin milling yang terdapat di laboratorium preparasi material Fisika UI Depok. Sampel bubuk ini kemudian dikarakterisasi dengan SEM untuk melihat ukuran butirnya. Masingmasing sampel berbentuk bubuk ini kemudian dicetak dengan menggunakan dies berdiameter 1 $\mathrm{cm}$ dan tebal $0,5 \mathrm{~cm}$ kemudian dipressing dengan tekanan sebesar 10 ton sehingga diperoleh sampel berbentuk tablet. Sampel yang telah berbentuk tablet ini kemudian diletakkan dalam wadah keramik tahan panas dan ke dalamnya dicampur magnesium sesuai dengan komposisi yang telah 
diperhitungkan dengan menggunakan persamaan reaksi kimia sebagai berikut :

$$
\begin{gathered}
2 \mathrm{~B}_{2} \mathrm{O}_{3}(\mathrm{~s})+6 \mathrm{C}(\mathrm{s})+\mathrm{Mg}(\mathrm{s}) \rightarrow \mathrm{B}_{4} \mathrm{C}(\mathrm{s})+ \\
\mathrm{MgO}(\mathrm{s})+5 \mathrm{CO}(\mathrm{g})
\end{gathered}
$$

Selanjutnya dilakukan proses sintering di dalam furnace gas dengan temperatur $850^{\circ} \mathrm{C}$ selama 24 jam. Setelah proses sintering selesai diperoleh material berwarna hitam. Material yang diperoleh kemudian dihaluskan dengan menggunakan mortar sehingga diperoleh hasil berbentuk bubuk.

\subsection{Karakterisasi Sampel Dengan Hamburan Sinar-X}

Sampel hasil preparasi dan sintering dipadatkan menjadi bentuk pellet kemudian ditempatkan pada bagian tengah sample holder dengan bantuan plastisin secukupnya. Sampel holderinikemudianditempatkan padasampel-stage di dalam sistem instrumen XRD. Instrumen XRD Fisika UNS dijalankan dengan parameter sebagai berikut: target $\mathrm{Cu}$ dengan $\mathrm{CuKa}=1,540598$. dan rentang $2 \theta$ dari $10^{\circ}$ s.d. $80^{\circ}$, tegangan $40 \mathrm{kV}$ dan arus $30 \mathrm{~mA}$ dan kecepatan scanning diffractometer 40/menit. Untuk instrumen XRD Material Sains UI Salemba: target Co dengan CoKá $=1,778$. dan rentang $2 \theta$ dari $15^{\circ}$ s.d. $80^{\circ}$, tegangan $40 \mathrm{kV}$ dan arus $30 \mathrm{~mA}$, dan kecepatan scanning diffractometer 10/menit Sinar $x$ yang dipancarkan dari tabung sinar $x$ mengenai sampel yang berada pada pusat geometer dan terdifraksi menurut hukum Bragg. Sudut difraksi dan intensitas dari sinar $\mathrm{x}$ didapat dengan melakukan scanning sampel dan detektor yang ada pada goneometer dengan sudut $2 \theta$ dari $15^{\circ}$ sampai $80^{\circ}$ (untuk XRD UI Salemba) dan $2 \theta$ dari $10^{\circ}$ sampai $80^{\circ}$ (untuk XRD UNS). Peralatan dihubungkan dengan IBM-PC software Automated Powder Diffraction (APD) dengan demikian intensitas difraksi dan sudut $2 \theta$ dapat ditampilkan pada layar monitor. Intensitas sinar $x$ ditunjukkan sebagai tinggi puncak. Selanjutnya dengan menggunakan software tersebut dapat diperoleh data-data sudut $2 \theta$ dan intensitas relative serta luasan total dibawah setiap puncak dari sampel. Kemudian nilai $2 \theta$ dari setiap puncak yang dihasilkan dicocokkan dengan data pada software ICDD PCPDFWIN. Data ini dan hasil difraktogram kemudian diolah dengan menggunakan software GSAS (General Structure Analysis System) untuk menentukan struktur kristal dari fasafasa yang mungkin terbentuk dalam sampel dengan terlebih dahulu dilakukan konversi file dari .udf atau .txt dengan menggunakan software Bella versi 2.21. Perangkat lunak GSAS ini dikembangkan oleh Allen C. Larson dan Robert B. Von Dreele dari
Los Alamos National Laboratory, USA dan diinstall dalam sebuah PC Pentium IV dengan RAM 128 MB dan software Bella versi 2.21 dikembangkan oleh Dr. M. Hikam dari Material Sains UI, Indonesia. Data hasil GSAS inilah yang kemudian menjadi dasar untuk analisis struktur material yang dihasilkan.

\subsection{Karakterisasi Bahan Awal Dengan DTA dan DSC}

DTA merupakan teknik analisis termal yang menggunakanperbedaantemperaturantarasampel dan referensi untuk menganalisis perubahan sifat kimia dan fisika. Keduanya dipanaskan dengan kondisi dan laju temperatur yang sama. Prinsip kerja DTA adalah mengukur perbedaan temperatur antara sampel dan referensi yang mana keduanya dihubungkan secara berlawanan dengan termokopel. Jika sampel dan referensi dipanaskan dengan laju sama dengan cara menaruh dalam tungku yang sama, maka temperatur keduanya akan naik. Temperatur referensi naik dengan laju tetap karena dipilih dari bahan yang tidak akan mengalami transisi fisika atau kimia. Temperatur sampel juga akan naik dengan laju tetap jika tidak terjadi transisi. Apabila sampel mengalami transisi maka kalor akan diserap sehingga temperatur sampel akan sedikit terlambat. Setelah transisi selesai maka temperatur sampel akan kembali dengan laju tetap.

\subsection{Karakterisasi Hasil dengan Fourier Transform Infrared (FTIR)}

Dua variasi instrumental dari spektroskopi inframerah (IR) adalah metode dispersif dan metode Fourier transform (FT). Metode dispersive menggunakan prisma atau kisi untuk mendispersikan radiasi inframerah, sedangkan metode Fourier transform menggunakan prinsip interferometri. Kelebihan-kelebihan dari FTIR mencakup persyaratan ukuran sampel yang kecil, perkembangan spektrum yang cepat, dan karena instrumen ini memiliki komputer yang terintegrasi sehingga memiliki kemampuan untuk menyimpan dan memanipulasi spektrum. (Instrumen-instrumen dispersive modern juga telah dilengkapi dengan mikrokomputer-mikrokomputeruntukpenyimpanan dan manipulasi spektrum). Spektrum spektrum dispersif dari sebagian material komersial telah dicatat, oleh karenanya identifikasi kualitatif zat-zat yang tidak diketahui seringkali bisa diselesaikan melalui perbandingan. 


\section{HASIL PENELITIAN DAN PEMBAHASAN}

\subsection{Karakterisasi Bahan Awal dengan DTA dan DSC}

Dalam metode DTA atau DSC suatu sampel bahan awal dan inert dipanaskan dalam atmosfer nitrogen, dan kemudian transisi-transisi termal dalam sampel bahan-bahan awal tersebut dideteksi dan diukur. Pemegang (holder) sampel yang paling umum dipakai adalah cangkir aluminium sangat kecil (emas atau grafit dipakai untuk analisis-analisis di atas $800^{\circ} \mathrm{C}$ ), dan referensinya berupa cangkir kosong atau cangkir yang mengandung bahan inert dalam daerah temperatur yang diinginkan, misalnya alumina bebas air. Ukuran sampel yang digunakan dalam penelitian ini masing-masing $10 \mathrm{mg}$. Meskipun DTA dan DSC memberikan tipe informasi yang sama, terdapat perbedaan yang signifikan dalam instrumentasinya. Dengan DTA, sampel dan referensi keduanya dipanaskan oleh sumber pemanasan yang sama, dan dicatat perbedaan temperatur (.T) antara keduanya. Ketika terjadi suatu transisi dalam sampel tersebut - misalnya, peleburan atau kristalisasi - temperatur sampel akan tertinggal di belakang temperatur referensi jika transisi tersebut endotermik, dan akan mendahului jika transisi tersebut eksotermik. Dengan DSC, sampel dan referensi diberikan dengan pemanasnya sendiri-sendiri, dan energy disuplai untuk menjaga suhu-suhu sampel dan referensi agar tetap konstan. Dalam hal ini, perbedaan daya listrik antara sampel dan referensi (d.Q/dt) dicatat. Data diplot sebagai .T (untuk DTA) atau $d . Q / d t$ (untuk DSC) di atas ordinat (sumbu y) versus temperatur di atas absis (sumbu $\mathrm{x}$ ). Plotplot demikian disebut termogram (Gambar 4.1, 4.2, 4.3, dan 4.4). Meskipun .T dan $d . Q / d t$ tidak proporsional secara linear, keduanya mempunyai kaitan dengan kapasitas panas.

Dengan demikian, termogram-termogram DTA dan DSC memiliki bentuk sama. Keuntungan utama DSC adalah bahwa area-area peak termogram berkaitan langsung dengan perubahan entalpi dalam sampel, oleh karenanya bisa dipakai untuk pengukuran-pengukuran kapasitas panas, panas fusi, entalpi reaksi, dan sejenisnya. Bahanbahan awal yang diuji adalah asam borat, asam sitrat, karbon aktif, dan grafit. Gambar4.1 merupakan termogram DTA asam borat. Dari termogram ini diperoleh informasi tentang tiga transisi yang terjadi pada asam borat ketika dipanaskan dalam rentang temperatur $25^{\circ} \mathrm{C}$ s.d. $450^{\circ} \mathrm{C}$, yang masing-masing puncak (peak) ditandai dengan abjad $A, B$, dan C. Peak A yang bersesuaian dengan temperatur $95^{\circ} \mathrm{C}$ merupakan temperatur transisi gelas $(\mathrm{Tg})$ dari asam borat. Ketika suatu asam organic maupun anorganik dipanaskan, energi kinetik molekul-molekulnya bertambah. Namun geraknya masih dibatasi sampai vibrasi dan rotasi pada rentang pendek sepanjang bahan tersebut mampu mempertahankan struktur gelasnya (padat). Ketika temperatur lebih dinaikkan lagi, maka muncul satu batas dimana terjadi suatu perubahan yang jelas, bahan melepaskan sifat-sifat gelasnya dan mengambil sifat-sifat yang umumnya lebih condong kepada sifat mengalir (cair). Temperatur pada saat berlangsungnya fenomena ini disebut temperatur transisi gelas $(\mathrm{Tg})$. Jika pemanasan dilanjutkan, bahan akan melebur menjadi cairan yang bisa mengalir. Perubahan lainnya dari sifat makroskopis yang terjadi pada transisi gelas ini, yaitu terdapat perubahan entalpi.

Pada puncak $B$ yang bersesuaian dengan temperatur $145^{\circ} \mathrm{C}$, terjadi transisi endotermik. Transisi ini merupakan titik lebur ( $\mathrm{Tm}$ ) asam borat. Pada saat ini seluruh asam borat yang tadinya berada pada fasa padat berupa kristal berwarna putih berubah menjadi cair seluruhnya. Pada puncak $C$ yang bersesuaian dengan temperatur $170^{\circ} \mathrm{C}$, terjadi transisi endotermik untuk yang kedua kalinya. Pada puncak ini terjadi peristiwa dehidrasi asam borat dan kristalisasi. Asam borat kehilangan air dan membentuk asam metaborat berupa suatu bentuk padatan berwarna putih dengan sistem kristal kubik.

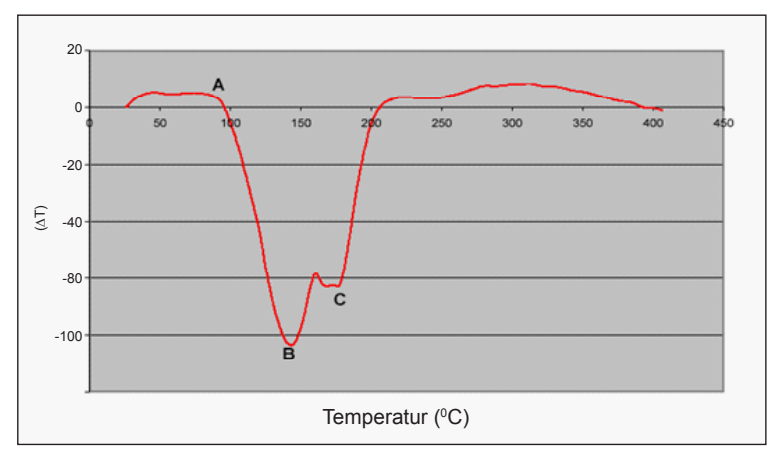

Gambar 4.1 Termogram DTA Asam borat

Gambar 4.2 merupakan termogram DSC untuk asam sitrat. Dari termogram ini diperoleh informasi bahwa terdapat empat transisi yang terjadi pada asam sitrat ketika dipanaskan dalam rentang temperatur $25^{\circ} \mathrm{C}$ s.d. $500^{\circ} \mathrm{C}$, yang masing-masing puncak (peak) ditandai dengan abjad A, B, C, dan $D$. Peak $A$ yang bersesuaian dengan temperatur $63^{\circ} \mathrm{C}$ merupakan temperatur transisi gelas $(\mathrm{Tg})$ dari asam sitrat. Pada puncak B yang bersesuaian dengan temperatur $78^{\circ} \mathrm{C}$, terjadi transisi endotermik. Transisi ini merupakan titik lebur (Tm) asam sitrat. Pada puncak $\mathrm{C}$ yang bersesuaian dengan temperatur $153^{\circ} \mathrm{C}$, terjadi transisi endotermik. Pada saat ini terjadi dekomposisi awal asam sitrat atau dehidrasi (kehilangan air). Pada puncak D 
yang bersesuaian dengan temperatur $207^{\circ} \mathrm{C}$, terjadi transisi endotermik. Pada saat ini terjadi dekomposisi akhir (pemutusan ikatan rangkap) asam sitrat, dan asam sitrat akan terdekomposisi termal menjadi $\mathrm{CO}_{2}$ dan karbon.

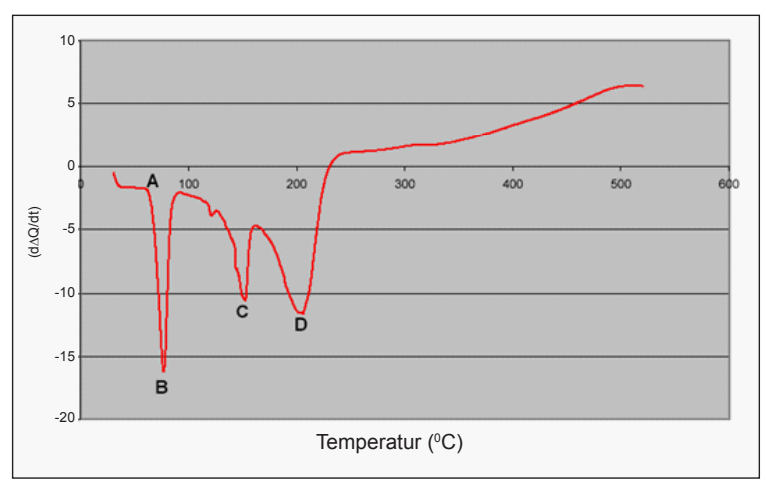

Gambar 4.2 Termogram DSC asam sitrat

Gambar 4.3 merupakan termogram DTA untuk karbon aktif. Pada puncak yang bersesuaian dengan temperatur $78^{\circ} \mathrm{C}$, terjadi transisi endotermik. Transisi pada peak ini diduga terjadi penguapan pengotor-pengotor organik yang terdapat dalam karbon aktif. Ketidakjelasan puncakpuncak eksotermis dari termogram kemungkinan disebabkan karbon aktif yang digunakan adalah karbon aktif komersial yang sebelumnya tidak dikenai perlakuan pencucian dengan larutan $\mathrm{HCl}$ untuk menghilangkan impuritas organik dan abu (ash).

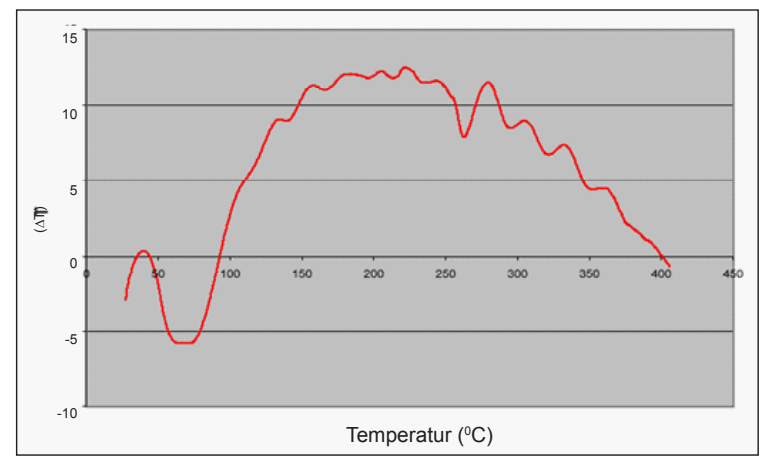

Gambar 4.3 Termogram DTA karbon aktif

Gambar 4.4 merupakan termogram DSC untuk grafit. Dari termogram ini jelas terlihat bahwa grafit yang digunakan hampir tidak mempunyai pengotor organik (impuritas). Hal ini ditandai dengan tidak adanya peak eksotermis selama temperatur pemanasan dari $100^{\circ} \mathrm{C}$ hingga $500^{\circ} \mathrm{C}$. Tidak adanya peak endotermis maupun eksotermis pada termogram DSC dari grafit pada rentang temperatur $100^{\circ} \mathrm{C}$ hingga $500^{\circ} \mathrm{C}$, mengindikasikan bahwa titik lebur atau penguraian termal grafit berada pada temperatur yang sangat tinggi.

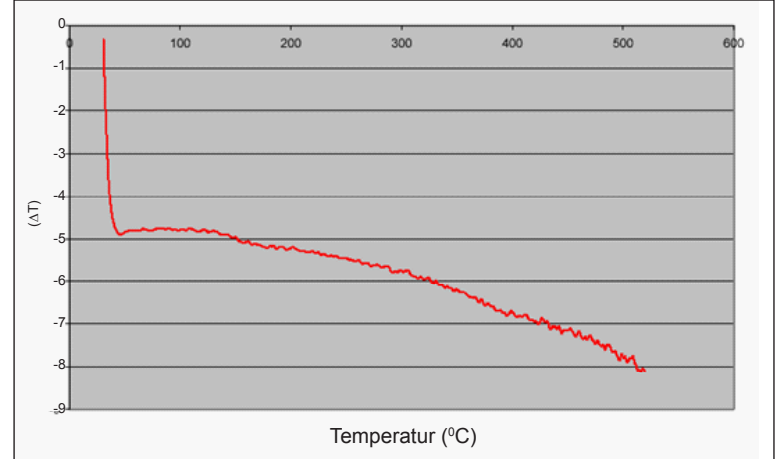

Gambar 4.4 Termogram DSC grafit

\subsection{Analisis Fasa dan Struktur Kristal}

Data yang diperoleh dari pengukuran sampel dengan XRD berupa data antara intensitas terhadap sudut $2 \theta$. Sudut $2 \theta$ tiap puncak intensitas hasil pengukuran XRD dicocokkan dengan material yang ada di software data ICDD. Untuk mengetahui komposisi sampel secara kualitatif dan kuantitatifnya dilakukan komputerisasi dengan metode GSAS. Dari data ini diketahui bahwa material yang dihasilkan dari percobaan berupa boron karbida dengan fasa $\mathrm{B}_{25} \mathrm{C}$ dan $\mathrm{B}_{4} \mathrm{C}$. Untuk material hasil pemanasan pada temperatur $850^{\circ} \mathrm{C}$ tanpa menggunakan koreduktor, tidak dilakukan analisis GSAS tetapi dilakukan pencocokan fasa dengan data ICDD. Hal ini dilakukan dengan alasan bahwa material tersebut belum menghasilkan fasa boron karbida yang diinginkan dari penelitian ini.

\subsubsection{Pola Difraksi dan Struktur Kristal Bahan Awal}

Profil hamburan sinar-x dari bahanbahan awal diperlihatkan pada Gambar 4.5, 4.6, 4.7 dan 4.8. Dari pola difraksi yang ada dan dicocokkan dengan data ICDD (PDF number 300620) menunjukkan bahwa asam borat $\left(\mathrm{H}_{3} \mathrm{BO}_{3}\right)$ mempunyai sistem kristal orthorombik, dengan grup ruang $1 \mathrm{P}(2)$, puncak-puncak utama difraksi dengan bidang orientasi (110), (100), dan (002), serta parameter kisi $a=7,039 \AA, b=7,064 \AA$, dan $c=6,585 \AA, \alpha=92,53^{\circ} \beta=101,20^{\circ} \gamma=119,88^{\circ}$. Dari pola difraksi untuk karbon aktif diketahui bahwa karbon aktif termasuk material amorf. Dari data ICDD (PDF number 75-1621) diketahui bahwa grafit memiliki sistem kristal heksagonal dengan space grup $\mathrm{P}_{63} \mathrm{mc}$, puncak-puncak difraksi dengan bidang orientasi (002) dan (101), parameter kisi $a=$ $b=4,470 \AA, c=6,790 \AA, \alpha=\beta=90^{\circ}, y=120^{\circ}$. Dari pola difraksi dan pencocokan dengan data ICDD (PDF number 16-1157) diketahui bahwa asam sitrat $\left(\mathrm{C}_{6} \mathrm{H}_{8} \mathrm{O}_{7}\right)$ memiliki sistem Kristal monoklinik 
dengan space grup P21/a, puncak-puncak difraksi dengan bidang orientasi (111), (011), (-201), (-313), (202), dan (201), dan parameter kisi $a=12,81 \AA$, b $=5,624 \AA, c=11,46 \AA, \alpha=\gamma=90^{\circ}, \beta=111,21^{\circ}$.

\subsubsection{Pola Difraksi dan Struktur Kristal Produk Akhir}

Untuk mengevaluasi distribusi komposisi bidang dominan pada material produk yang dihasilkan oleh kedua variasi komposisi untuk penambahan sitrat, jenis karbon yang digunakan, dan penggunaan koreduktormagnesium, digunakan profil hamburan sinar $x$ yang didapatkan dan dengan dari campuran karbon-karbon, boron-karbon, dan hidrogenoksigen. Pengukuran pita-pita absorpsi dari sampel penelitian dalam spektrum inframerah dari rentang 500 s.d. 4000 cm-1 ditampilkan dalam kurva transmisi. Pita-pita transmitansi (transmittance) pada 2200 s.d. 2400 cm-1 dalam spektra infrared muncul karena C-O stretching dari molekul $\mathrm{CO}_{2}$ atau diakibatkan oleh noise (bising) yang berasal dari peralatan. Pita absorpsi yang lebar pada 2800 s.d. 3700 cm-1 berkaitan dengan pita rentang $\mathrm{O}-\mathrm{H}$ dari uap yang terdapat dalam medium. Puncak kecil pada $732 \mathrm{~cm}^{-1}$ menunjukkan vibrasi dari boron magnesium. Puncak yang tinggi pada $1195 \mathrm{~cm}^{-1}$ dan $1461 \mathrm{~cm}^{-1}$ bersesuaian dengan

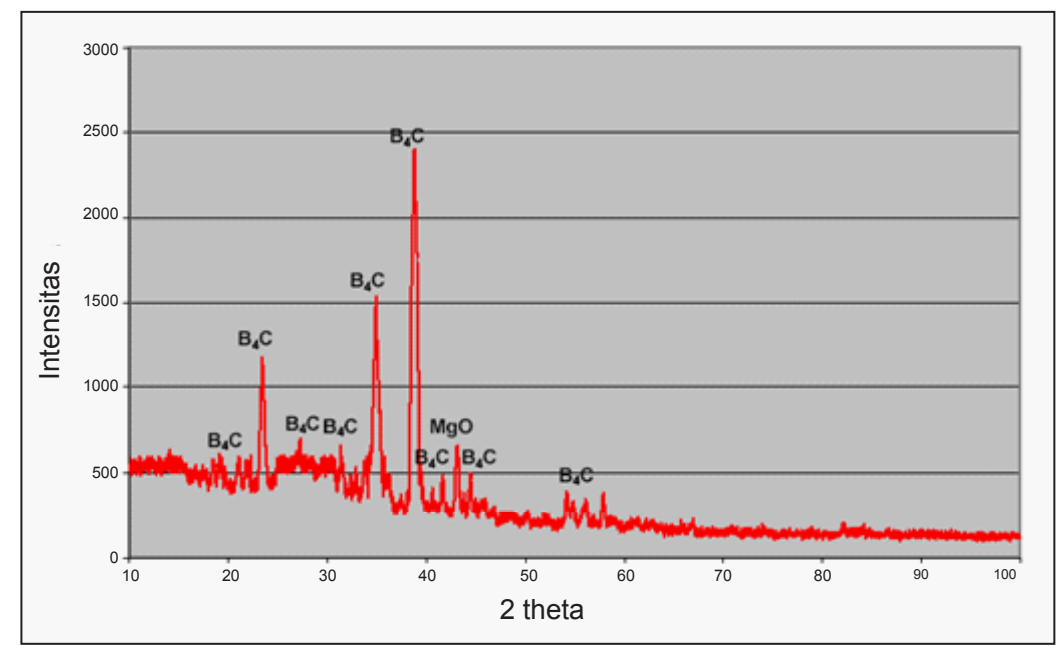

Gambar 4.5 Hasil difraksi XRD produk akhir dimana terbentuk $\mathrm{B}_{4} \mathrm{C}$

menggunakan data ICDD dengan nomor PDF 35-0798. Berdasarkan data ICDD dengan nomor PDF 35-0798 diketahui bahwa boron karbida $\mathrm{B}_{4} \mathrm{C}$ memiliki bidang-bidang kristal yang utama yaitu (003), (012), (104), dan (021) masing-masing pada $\sin 2 \theta=22^{\circ}, 23,5^{\circ}, 35^{\circ}$, dan $38^{\circ}$. Penelitian berhasil mendapatkan boron karbida B4C dengan bidangbidang utama berada pada sudut $2 \mathrm{è}=23^{\circ}, 35^{\circ}$, dan $38^{\circ}$.

\subsection{Karakterisasi Hasil dengan FTIR}

Untuk memferifikasi sudah terbentuknya fasa B4C pada sampel hasil penelitian, maka dilakukan karakterisasi dengan menggunakan FTIR (Fourier Transform InfraRed). Karakterisasi dengan FTIR bertujuan untuk menyelidiki ikatan-ikatan yang terbentuk dalam material hasil penelitian. Sampel hasil yang digunakan adalah sampel A2 yang telah dimilling selama 60 jam dan dipanaskan pada temperatur $850^{\circ} \mathrm{C}$ selama 24 jam. Ikatan yang terbentuk dalam material hasil ini antara lain ikatan $\mathrm{C}-\mathrm{O}, \mathrm{O}-\mathrm{H}$, dan ikatan boron karbon. Kebanyakan puncak-puncak dari pita dalam spektrum inframerah (FTIR) yang muncul pada produk akhir bersesuaian dengan rentang mode vibrasi kluster karbon-karbon dan karbon-boron, atau campuran boron karbon. Puncak-puncak kecil pada pita serap $628 \mathrm{~cm}^{-1}$ dan $547 \mathrm{~cm}^{-1}$ berkaitan dengan bending vibrasi dari ikatan boron-hidrogen. Puncak kecil pada pita $1033 \mathrm{~cm}^{-1}$ bersesuaian dengan rentang mode vibrasi dari atom pusat dari rantai yang terdiri dari tiga atom di dalam unit sel boron karbida (C- ${ }^{-11} \mathrm{~B}-{ }^{10} \mathrm{~B}$; C- ${ }^{10} \mathrm{~B}-\mathrm{C}$; $\mathrm{C}-{ }^{10} \mathrm{~B}-{ }^{11} \mathrm{~B}$; $\left.\mathrm{C}-{ }^{10} \mathrm{~B}-10 \mathrm{~B}\right)$, di mana $\mathrm{C}-{ }^{10} \mathrm{~B}-\mathrm{C}$ merupakan rantai utama. Dengan terbukti adanya ikatan boron-karbon ini maka hasil dari FTIR bersesuaian dengan hasil difraksi sinar $x$ yang mengindikasikan telah terbentuknya fasa $\mathrm{B}_{4} \mathrm{C}$.

\section{KESIMPULAN DAN SARAN}

Berdasarkan hasil dan pembahasan seperti yang telah dijelaskan pada bagian 4 dapat diperoleh kesimpulan bahwa:

1. Dari data hasil percobaan untuk sampel sampel yang disintering tanpa menggunakan koreduktor, belum terjadi pembentukan boron karbida dengan fasa B4C. Dari hasil pencocokan fasa material dengan data ICDD dan pengolahan data dengan software 
GSAS diketahui bahwa material yang terbentuk adalah boron karbida dengan fasa $B_{25} C$. Boron karbida dengan fasa $\mathrm{B}_{25} \mathrm{C}$ ini memiliki sistem kristal tetragonal, space grup P42/nnm, dan parameter kisi $a=8,753 \AA, b=8,753 \AA$, $c=5,093 \AA, \alpha=\beta=\gamma=90^{\circ}$.

2. Dari data hasil percobaan untuk sampel sampel yang disinterring dengan menggunakan koreduktor, telah terjadi pembentukan boron karbida dengan fasa $B_{4} C$. Boron karbida dengan fasa $\mathrm{B}_{4} \mathrm{C}$ ini memiliki sistem kristal rhombohedral, space grup $\mathrm{m} 3 \mathrm{R}$, dan parameter kisi $a=b=5,600, c=12,08$, $\alpha=\beta=\gamma=90^{\circ}$.

3. Reaksi dengan penambahan koreduktor magnesium berlangsung secara eksotermis. Selain itu ditambah dengan adanya gas CO sebagai reduktor oksida borat, maka pada temperatur $850^{\circ} \mathrm{C}$ dapat terjadi reaksi pembentukan boron karbida dengan fasa $\mathrm{B}_{4} \mathrm{C}$.

4. Untuk sumber karbon yang berasal dari karbon aktif yang telah terlebih dahulu dimodifikasi dengan cara mencucinya dengan larutan $\mathrm{HCl}$ yang memiliki beberapa variasi konsentrasi, terdapat beberapa pengaruh yang cukup signifikan, yaitu makin besar konsentrasi larutan $\mathrm{HCl}$ yang digunakan, makin banyak bidang-bidang yang terbentuk.

5. Makin tingginya intensitas hamburan sinar $x$ mengindikasikan terbentuknya lebih banyak kristal $\mathrm{B}_{4} \mathrm{C}$ pada sampel sampel yang menggunakan asam sitrat dibandingkan dengan sampel-sampel yang tidak menggunakan asam sitrat.

6. Reaksi fasa pada boron karbida terjadi melalui proses difusi dengan kecepatan relatif perlahan. Efektifitas reaksi ditentukan oleh jarak difusi yang pendek atau temperatur sintering yang tinggi atau waktu pemanasan yang panjang [4]. Dengan demikian, kesempurnaan reaksi juga ditentukan oleh efektifitas proses ball milling sebelum proses sintering. Makin lama waktu milling, diduga akan makin banyak boron karbida dengan fasa $\mathrm{B}_{4} \mathrm{C}$ yang terbentuk.

Berdasarkan hasil penelitian yang dilakukan maka masih perlu dikembangkan penelitianpenelitian lanjutan antara lain:

1. Perlu kelanjutan pengujian pengaruh proses ball milling terhadap sampel sampel yang lain dan variasi waktu milling terhadap pembentukan boron karbida.

2. Perlunya dilakukan penelitian lanjutan untuk mengamati pengaruh variasi komposisi koreduktor magnesium yang digunakan terhadap pembentukan boron karbida.

3. Perlunya dilakukan penelitian lanjutan dengan menggunakan inert gas (argon, nitrogen, atau hidrogen) dan vakum selama proses sintering untuk mengetahui efektifitas pembentukan boron karbida pada masing-masing metode.

\section{DAFTAR PUSTAKA}

Anselmi-Tamburini, U., Zuhair, A. M., Yasuhiro, K., Takahito, I., and Manshi, O., Influence of synthesis temperature on the defect structure of boron carbide: Experimental and modelling studies, J. Am. Ceram. Soc., 88 [6] (2005), P. 1382-1387

Austin, George, T., 1996, Industri proses kimia Jilid 1 Edis 5, Penerbit Erlangga, Jakarta

Cho, Namtae, Processing of Boron Carbide, Thesis, 2006, School of Materials Science and Engineering Geogia Institute of Technology

Khanra, A. K., Production of boron carbide powder by carbothermal synthesis of gel material, Bull. Mater. Sci., Vol. 30 (2007), P.93-96

Lazzari, R., N. Vast, J. M. Besson, S. Baroni, and A. Dal Corso, Atomic structure and vibrational properties of icosahedra B4C boron carbide, Phys. Rev. Lett. Vol. 83 (1999), P. 3230-3233

Mondal, S. and Ajit K. B., Low-temperature synthetic route for boron carbide, J. Eur. Ceram. Soc., 25 (2005), P. 287-291

Pender, M. J., Kersten, M. F., and Larry, G. S., Molecular and polymeric precursors to boron carbide nanofibers, nanocylinders, and nanoporous ceramics, Pure Appl. Chem., Vol. 75 (2003), P. 1287-1294

Ragone, David, V., 1995, Thermodynamics of Materials Vol. I and II, Jhon Wiley, New York

Reed, J, S., 1995, Principles of Ceramics Processing, 2nd Edition, Jhon Wiley, New York 
Rodriguez, M. G., Oxana, V. K., and U. Ortiz Mendez, Formation of boron carbide nanofibers and nanobelts from heated by microwave, Rev. Adv. Mater. Sci. 7 (2004), P. 55-60
Shi, et.al., A low temperature synthesis of crystalline $\mathrm{B}_{4} \mathrm{C}$ ultrafine powders, Solid state communication 128 (2003), P.5-7

Http//:www. wikipedia.com, Boron Carbide, Januari 2007 